\title{
Synthesis of 2,4-Disubstituted Thiazole Combinatorial Unit on Solid-Phase: Microwave Assisted Conversion of Alcohol to Amine Monitored by FT-IR
}

\author{
Dyeison Antonow ${ }^{*, a}$, S. Graciela Mahler ${ }^{b}$, Gloria L. Serra ${ }^{b}$, Eduardo Manta $^{b}$ and \\ Vera Lucia Eifler-Lima ${ }^{a}$ \\ ${ }^{a}$ Faculdade de Farmácia, Universidade Federal do Rio Grande do Sul, Porto Alegre - RS, Brazil \\ ${ }^{b}$ Departamento de Química Orgánica, Cátedra de Química Farmacéutica, Facultad de Química, \\ Universidad de la República, Montevideo, Uruguay.
}

\begin{abstract}
Síntese em fase sólida com auxílio de radiação de microondas do tiazol 2,4-dissubstituído 3 com Resina Merrifield é descrita. As reações envolveram a conversão do grupo hidroxila em amina em cinco etapas - incluindo acoplamento e clivagem - com redimento total de $26 \%$ em duas horas de tempo reacional. Todas etapas da rota sintética foram eficientemente monitoradas por FT-IR em discos de $\mathrm{KBr}$, demonstrando que esse método pode ser usado em química combinatória.
\end{abstract}

Microwave-assisted solid-phase synthesis of the 2,4-disubstituted thiazole 3 on Merrifield Resin is described. The hydroxyl moiety was converted to amine in five steps - including coupling and cleavage - within a total reaction time of 2 hours and $26 \%$ overall yield. The entire solid-phase synthesis was efficiently monitored by FT-IR/KBr pellets and allows potential use in combinatorial chemistry.

Keywords: thiazole, microwave, monitoring solid-phase reactions

\section{Introduction}

Solid-phase synthesis is a revolutionary approach which was originally developed for peptide synthesis but has been extended to a wide variety of organic syntheses. ${ }^{1}$ Solid-supported synthesis benefits from the ability to drive reactions to completion by use of excess reagents. Moreover, purification is simplified through simple filtration and washing of the on-bead products at each step. Microwave radiation has previously been employed for several types of solid-phase reaction, and it has shown to be an efficient method to improve yields and speed up library synthesis of discrete molecules. ${ }^{2}$ Despite the achievements in this area relatively few techniques have been suggested to fill the lack of alternatives to monitor solid-supported reactions. ${ }^{3}$ As a consequence, chemists perform reactions for longer than necessary when attempting to ensure complete conversion to the desire product. Though few methods thus far have been described

* e-mail: dyeison.antonow @ulsop.ac.uk

Present address: Cancer Research UK, Gene Targeted Drug Design Research Group, 29/39 Brunswick Square, The School of Pharmacy, London-UK, WC1N 1AX. to assess supported intermediates, FT-IR spectroscopy is emerging as an attractive alternative. ${ }^{4}$

In order to test the efficacy of microwave irradiation in conjunction with FT-IR analysis for solid-phase reactions we selected the thiazole building block 2 as a combinatorial scaffold. Interestingly, anthelmintic and antitumoral activity have been described for 2,4disubstituted thiazoles or thiazolidines. ${ }^{5}$ Mycothiazole, a natural product isolated from the marine sponge Spongia mycofijiensis, typifies this class of molecules. ${ }^{6}$ The synthesis of new mycothiazole analogues is desirable in the search for new pharmacologically active compounds. Herein, we describe the microwave-assisted solid-phase conversion of secondary alcohol $\mathbf{3}$ to its corresponding amine 7 (Scheme 1), potentially useful as a nucleophile in the synthesis of thiazole libraries. The previously reported ${ }^{7}$ KBr pellets/FT-IR method was successfully used to monitor each reaction step.

\section{Results and Discussion}

We have previously published the successful synthesis of building block $\mathbf{1}$, involving thiazole ring closure using Deoxo-Fluor $^{\circledR}$ followed by radical aromatization via 


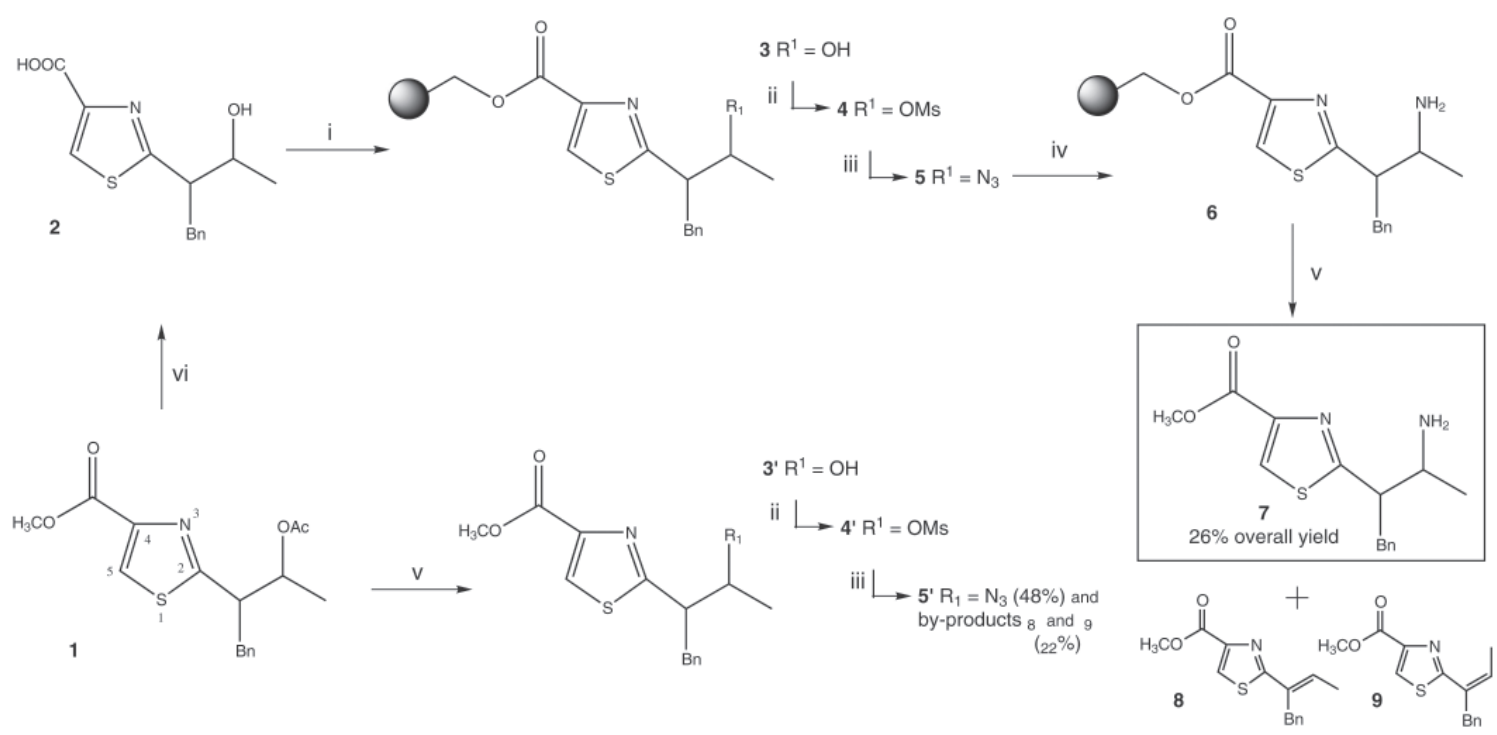

Scheme 1. Solid and solution phase synthesis of 7. Conditions: i) Merrifield Resin, $\mathrm{Cs}_{2} \mathrm{CO}_{3}, \mathrm{KI}, \mathrm{DMF}, \mathrm{MW}(90 \mathrm{w}), 12 \mathrm{~min} ;$ ii) $\mathrm{MsCl}_{2} \mathrm{Et}_{3} \mathrm{~N}, \mathrm{CH}_{2} \mathrm{Cl}_{2}$,

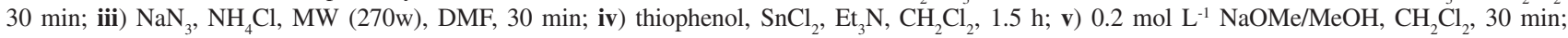
vi) $\mathrm{KOH}, \mathrm{MeOH} /$ water, r.t., 6 h.

$\mathrm{BrCCl}_{3}{ }^{8}$ Substrate 2 was loaded onto Merrifield resin, using $\mathrm{Cs}_{2} \mathrm{CO}_{3}$ and $\mathrm{KI}$ in DMF under microwave radiation, to give 3 within 5 minutes. This protocol is frequently cited in the literature as requiring 16 hours or longer without the assistance of microwave. ${ }^{9}$ The progress of the reaction was evaluated throughout its course by FT-IR (KBr pellets). ${ }^{7}$ The appearance of a $\mathrm{C}=\mathrm{O}$ vibration at $1736 \mathrm{~cm}^{-1}$ was measured, which confirmed its completion within 5 minutes (Figure 1A). Subsequent mesylation of $\mathbf{3}$ provided the leaving group needed for the next step. This reaction was monitored by following the absorption of the $\mathrm{SO}_{2}$ symmetric stretch vibration $\left(1174 \mathrm{~cm}^{-1}\right)$. Figure $1 \mathrm{~B}$ shows that sulfonate formation was completed within 10 minutes. Nucleophilic substitution by azide, also assisted by microwave radiation, resulted in rapid appearance of a $2093 \mathrm{~cm}^{-1}$ band attributed to a $-\mathrm{N}=\mathrm{N}^{+}=\mathrm{N}^{-}$out-of-plane
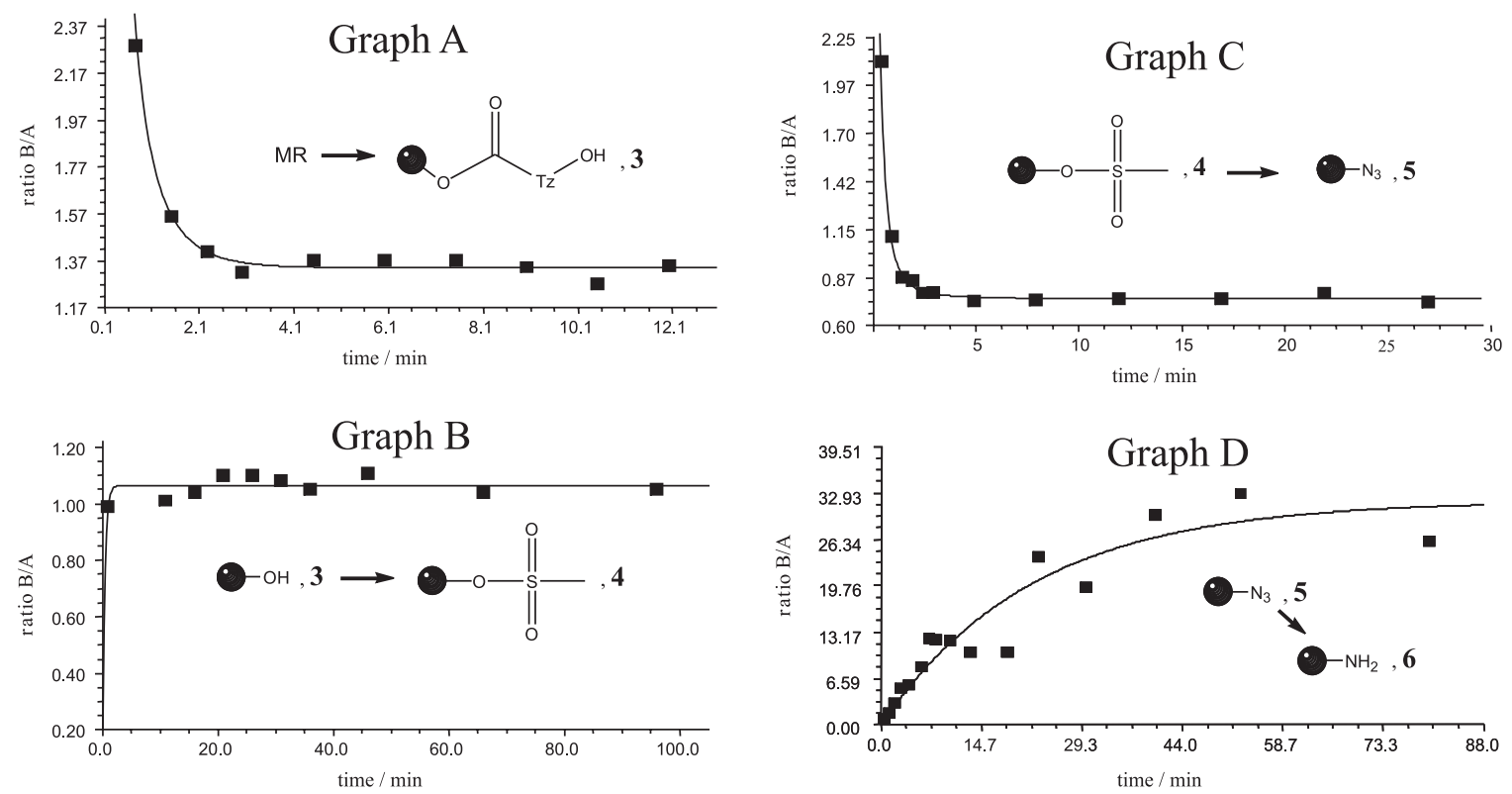

Figure 1. Solid-phase reactions monitored by FT-IR illustrating the bond of interest. The graphs were obtained by comparing the band's height to a reference generating the ratio $\mathrm{B} / \mathrm{A} .{ }^{7}$ Graph $\mathrm{A}: \mathrm{A}=\mathrm{C}=\mathrm{O}$ axial vibration $\left(1736 \mathrm{~cm}^{-1}\right)$ and $\mathrm{B}=\mathrm{C}-\mathrm{C}$ axial deformation from aromatic ring in the polystyrene resin $\left(1450 \mathrm{~cm}^{-1}\right)$. Graph $\mathbf{B}: \mathrm{A}=\mathrm{C}=\mathrm{O}(1736.5 \mathrm{~cm}-1)$ and $\mathrm{B}=\mathrm{S}=\mathrm{O}$ symmetric vibration $(1174 \mathrm{~cm}-1) . \mathrm{Graphs} \mathbf{C}$ and $\mathbf{D}: \mathbf{A}=\mathrm{N}^{-} \mathrm{N}^{+}=\mathrm{N}^{-}$ vibration $\left(2093 \mathrm{~cm}^{-1}\right)$ and $\mathrm{B}=\mathrm{C}-\mathrm{C}\left(1450 \mathrm{~cm}^{-1}\right)$. 
stretch vibration, again indicating very fast completion of the reaction (Figure 1C).

Though many methods of azide reduction are described in the literature,$^{10}$ not all are appropriate for solid-phase synthesis due to poor compatibility of some reagents with the polymeric matrix. For our desired on-bead reduction, however, we successful utilised thiophenol as an electrontransfer reagent in the presence of $\mathrm{SnCl}_{2}$. The gradually disappearance of absorption at $2093 \mathrm{~cm}^{-1}$ confirmed complete reduction in 1.5 hours (Figure 1D). Cleavage of the product from the solid-supported was carried out with sodium methoxide. ${ }^{11}$ Complete disappearance of the resinbound ester carbonyl band $\left(1736 \mathrm{~cm}^{-1}\right)$ indicated that the substrate was totally released after 30 minutes (graph not shown) in a satisfactory yield of $26 \%$ over five steps. TLC analysis of the filtrate showed the presence of the desired amine and also some faster-running impurities, which were purified and identified by ${ }^{1} \mathrm{H}$ NMR as vinyl products $(\mathbf{8}$ and 9). In order to understand the origin of these alkene products the analogous synthetic pathway was performed in solution-phase.

Solution-phase synthesis started by selective deprotection of $\mathbf{1}$ using transesterification conditions, which were also applied to release the substrate at the last step of the solid-phase sequence. The mesylation was performed with slightly less reagent in comparison to the equivalent on-bead reaction. For the subsequent solutionphase nucleophilic substitution the azide group was successfully installed with reasonable yield (48\%), but only under microwave radiation; thus emphasizing the importance of microwave for this reaction. Results however, clearly indicated that during this step a simultaneous undesirable competing elimination occurred to yield the by-products 8 and $\mathbf{9}(22 \%)$.

\section{Conclusions}

Solid-phase reactions involving the conversion of a hydroxyl group in the thiazole template were shown to be a quick and easy method to obtain target amine within a total reaction time of 2 hours. This is an important aspect for the purposes of building library compounds. Microwave radiation drastically reduced the reaction times of the coupling and azide substitution steps. The undesirable elimination did not represent a serious disadvantage for the synthesis proposed as the target product 7 was obtained successfully in acceptable yield using immobilized intermediates. The FT-IR ( $\mathrm{KBr}$ pellets) spectroscopy technique was used successfully to monitor the entire solidphase synthesis and showed that many reactions can be carried out in shorter times than those usually specified.

\section{Experimental}

\section{General}

All FT-IR spectra were recorded on a Shimadzu DR 8001 Spectrophotometer following a previously published method. ${ }^{7}$ One- and two-dimensional ${ }^{1} \mathrm{H}$ and ${ }^{13} \mathrm{C}$ NMR were measured either at 300 and $75 \mathrm{MHz}$ respectively, using an Inova-300 or at 400 and $100 \mathrm{MHz}$ respectively, using a Bruker Avance NMR spectrometer. Samples were dissolved in $\mathrm{CDCl}_{3}$, and chemical shifts are reported as $\delta$ values (ppm) relative to TMS. The mass spectra were collected using a Waters Micromass ZQ coupled to a Waters 2695 HPLC and a Waters 2996 PDA. Waters Micromass ZQ parameters: Capillary (kV) 3.38; Cone (V) 35; Extractor (V) 3.0; Source temperature $\left({ }^{\circ} \mathrm{C}\right) 100$; Desolvation Temperature $\left({ }^{\circ} \mathrm{C}\right) 200$; Cone flow rate $(\mathrm{L} / \mathrm{h}) 50$; Desolvation flow rate $(\mathrm{L} / \mathrm{h}) 250$. The HPLC was run using a mobile phase water (A) (formic acid $0.1 \%$ ) and acetonitrile (B) (formic acid 0.1\%). Gradient: initial composition 5\% B, to $95 \%$ B over 4 minutes. Held for 3 minutes at $95 \% \mathrm{~B}$, returned to $5 \% \mathrm{~B}$ in 0.2 minutes. Total run time: $9 \mathrm{~min}$, flow rate: $1.5 \mathrm{~mL} \mathrm{~min}^{-1} .200 \mu \mathrm{L}$ was split via a zero dead volume tee piece which pass into the mass spectrometer. Column Phenomenex ${ }^{\circledast}$ LURIA $3 \mu$ C18(12) 100A 50x $4.60 \mathrm{~mm}$. Alternatively mass analyses were performed by loop injection using a GC-MS Shimadzu QP 1100-EX. Microwave-assisted reactions were carried out in a Sharp (Carousel I) domestic microwave oven.

All anhydrous solvents were dried according to the literature methods. ${ }^{12}$ Reactions requiring anhydrous conditions were conducted using glassware dried with a heating-gun under positive pressure of dry nitrogen. Merrifield resin was purchased from Aldrich (loading 2.0$2.5 \mathrm{mmol} \mathrm{g}^{-1}, 1 \%$ cross-linked) and reaction stoichiometries were calculated assuming $2.5 \mathrm{mmol} \mathrm{g}^{-1}$. A diastereomeric mixture of thiazoles $\mathbf{1}$ was used as synthetic precursor.

\section{Synthetic procedures (Scheme 1)}

2-(1-benzyl-2-hydroxy-propyl)-thiazole-4-carboxylic acid (2). To a solution of $\mathbf{1}(200 \mathrm{mg}, 0.60 \mathrm{mmol}, 1.0$ Equiv.) in methanol $(1 \mathrm{~mL})$ was added $\mathrm{KOH}(135 \mathrm{mg}, 2.4 \mathrm{mmol}$, 4.0 Equiv.) dissolved in water $(2 \mathrm{~mL})$. The mixture was stirred at room temperature for $6 \mathrm{~h}$. Work-up involved acidification to $\mathrm{pH} 3(50 \% \mathrm{HCl})$ and subsequent extraction with EtOAc ( $3 \times 5 \mathrm{~mL})$. The organic layers were combined, dried over $\mathrm{Na}_{2} \mathrm{SO}_{4}$ and concentrated under vacuum to afford 2 as an off-white solid. (163 mg, 98\%) (2) IR (KBr pellet) $v_{\max } / \mathrm{cm}^{-1}: 3410,3117,2928,1717(\mathrm{C}=\mathrm{O}), 1495,1454$, $1379,1217,1115,1100,1069,1032,964,922,899,866$, 752, 700. ${ }^{1} \mathrm{H}$ NMR $\left(\mathrm{CDCl}_{3}, 400 \mathrm{MHz}\right) \delta 1.20(\mathrm{~d}, 3 \mathrm{H}, J 6.4$ 
$\mathrm{Hz}, \mathrm{CH}_{3}$ ), 3.12-3.22 (m, $\left.2 \mathrm{H}, \mathrm{CH}_{2}\right), 3.46-3.50$ (m, $\left.1 \mathrm{H}, \mathrm{CH}\right)$, 4.16 - 4.20 (m, $1 \mathrm{H}, \mathrm{CHOH}), 7.10-7.28$ (m, $5 \mathrm{H}, \mathrm{Ar}$ ), 8.18 (s, $1 \mathrm{H}, \mathrm{CH} 5) .{ }^{13} \mathrm{C} \mathrm{NMR}\left(\mathrm{CDCl}_{3}, 100 \mathrm{MHz}\right): \delta 172.4$ (C2), 164.3 (C=O), 146.1 (C4), 138.9 (Ar), 129.4 (Ar), 129.0 (Ar), 128.9 (C5), 127.0 (Ar), $68.7(\mathrm{COH}), 52.9(\mathrm{CH}), 39.9\left(\mathrm{CH}_{2}\right)$, $20.6\left(\mathrm{CH}_{3}\right)$. MS (EI, $\left.70 \mathrm{eV}\right) \mathrm{m} / z$ (rel. intensity) $91.2\left([\mathrm{Bn}]^{+}\right.$, $100 \%), 186.3\left([\mathrm{M}-\mathrm{Bn}]^{+}, 37.66 \%\right), 277.3\left([\mathrm{M}+\mathrm{H}]^{+}, 1.74 \%\right)$.

2-(1-Benzyl-2-hydroxy-propyl)-thiazole-4-carboxylic acid methyl ester (3'). To a solution of $\mathbf{1}$ (300 mg, 0.90 mmol, 1.0 Equiv.) in dry $\mathrm{CH}_{2} \mathrm{Cl}_{2}(4 \mathrm{~mL})$ was added a freshly prepared $0.2 \mathrm{~mol} \mathrm{~L}^{-1}$ sodium methoxide solution in methanol ( $2 \mathrm{~mL}, 0.40 \mathrm{mmol}, 0.45$ Equiv). The reaction was heated at reflux for 30 minutes. The excess solvent was then evaporated under vacuum and the resulting oil was subjected to flash chromatography (Cyclohexane/ EtOAc 7:3), affording 3' as colorless oil. (217 mg, $83 \%$ ) IR (film) $v_{\max } / \mathrm{cm}^{-1}: 3400$ (br, OH), 3115, 2968, $1738(\mathrm{C}=\mathrm{O})$, 1495, 1454, 1346, 1325, 1219, 1098, 1067, 993, 779, 754, 700. ${ }^{1} \mathrm{H}$ NMR $\left(\mathrm{CDCl}_{3}, 300 \mathrm{MHz}\right) \delta 1.14(\mathrm{~d}, 3 \mathrm{H}, J 6.6 \mathrm{~Hz}$, $\mathrm{CH}_{3}$ ), 3.22-3.44 (m, $\left.2 \mathrm{H}, \mathrm{CH}_{2}\right), 3.45-3.48$ (m, $\left.1 \mathrm{H}, \mathrm{CH}\right), 3.94$ (s, $\left.3 \mathrm{H}, \mathrm{OCH}_{3}\right), 4.05$ - 4.20 (m, $\left.1 \mathrm{H}, \mathrm{CHOH}\right), 7.13$ - 7.28 (m, $5 \mathrm{H}, \mathrm{Ar}), 8.07$ (s, $1 \mathrm{H}, \mathrm{CH} 5) .{ }^{13} \mathrm{C} \mathrm{NMR}\left(\mathrm{CDCl}_{3}, 75 \mathrm{MHz}\right): \delta$ 171.5 (C2), 161.7 (C=O), 145.7 (C4), 138.5 (Ar), 128.9 (Ar), 128.2 (Ar), 126.9 (C5), 126.3 (Ar), 69.2 (COH), 52.4 $(\mathrm{CH}), 52.2\left(\mathrm{OCH}_{3}\right), 36.1\left(\mathrm{CH}_{2}\right), 20.2\left(\mathrm{CH}_{3}\right)$.

2-(1-Benzyl-2-methanesulfonyloxy-propyl)-thiazole-4carboxylic acid methyl ester (4'). To a solution of 3' (100 $\mathrm{mg}, 0.34 \mathrm{mmol}, 1.0$ Equiv.) in dry $\mathrm{CH}_{2} \mathrm{Cl}_{2}(1.5 \mathrm{~mL})$ was added dry triethylamine $(0.07 \mathrm{~mL}, 0.52 \mathrm{mmol}, 1.5$ Equiv) and mesyl chloride (0.03 mL, $0.38 \mathrm{mmol}, 1.1$ Equiv.). After 30 minutes at room temperature TLC indicated total consumption of the starting material. The mixture was concentrated in vacuo, followed by addition of water at pH 3 ( $\mathrm{HCl} 5 \%)$, and extraction with EtOAc (4 x $3 \mathrm{~mL})$. The resulting oil was purified by flash chromatography (cyclohexane/EtOAc 8:2) to give 4' was a white solid. (98.1 $\mathrm{mg}, 78 \%$ ). IR (KBr pellet) $v_{\max } / \mathrm{cm}^{-1}: 3102,2942,1725$ ( $\mathrm{C}=\mathrm{O}), 1478,1454,1329$ ( $\mathrm{S}=\mathrm{O}$ asym.), 1217, 1171 ( $\mathrm{S}=\mathrm{O}$ sym.), 1103, 1066, 965, 892, 817, 774, 748, 698, 619. ${ }^{1} \mathrm{H}$ NMR $\left(\mathrm{CDCl}_{3}, 400 \mathrm{MHz}\right) \delta 1.51\left(\mathrm{~d}, 3 \mathrm{H}, J 6.4 \mathrm{~Hz}, \mathrm{CH}_{3}\right)$, 2.93 (s, $\left.3 \mathrm{H}, \mathrm{CH}_{3}, \mathrm{Ms}\right), 3.12-3.24$ (m, $\left.2 \mathrm{H}, \mathrm{CH}_{2}\right), 3.76-3.81$ (m, $1 \mathrm{H}, \mathrm{CH}), 3.96$ (s, $\left.3 \mathrm{H}, \mathrm{OCH}_{3}\right), 5.15(\mathrm{~m}, 1 \mathrm{H}, J 6.2 \mathrm{~Hz}$, CHOMs), 7.09-7.28 (m, $5 \mathrm{H}, \mathrm{Ar}), 8.11$ (s, $1 \mathrm{H}, \mathrm{CH} 5) .{ }^{13} \mathrm{C}$ $\mathrm{NMR}\left(\mathrm{CDCl}_{3}, 100 \mathrm{MHz}\right): \delta 169.9(\mathrm{C} 2), 162.1(\mathrm{C}=\mathrm{O}), 146.6$ (C4), 137.8 (Ar), 129.5 (Ar), 128.9 (Ar), 128.6 (C5), 127.2 (Ar), $79.8(\mathrm{COMs}), 52.8\left(\mathrm{OCH}_{3}\right), 51.9(\mathrm{CH}), 39.2\left(\mathrm{CH}_{3}, \mathrm{Ms}\right)$, $38.6\left(\mathrm{CH}_{2}\right), 20.0\left(\mathrm{CH}_{3}\right)$. MS (EI, $\left.70 \mathrm{eV}\right) \mathrm{m} / \mathrm{z}$ (rel. intensity) $90.9\left([\mathrm{Bn}]^{+}, 59.4 \%\right), 246.2\left(\left[\mathrm{M}-\mathrm{Bz}_{-} \mathrm{OCH}_{3}\right]^{+}, 100 \%\right), 273.2$ ([M - OMs $\left.]^{+}, 77.1 \%\right), 369.1\left([\mathrm{M}+\mathrm{H}]^{+}, 100 \%\right)$.

2-(2-Azido-1-benzyl-propyl)-thiazole-4-carboxylic acid methyl ester (5'). To a solution of 4' (93 mg, 0.25 mmol, 1.0 Equiv.) in dry DMF $(0.5 \mathrm{~mL})$ in a small conical flask was added $\mathrm{NaN}_{3}$ (42 mg, $0.90 \mathrm{mmol}, 2.6$ Equiv.) and $\mathrm{NH}_{4} \mathrm{Cl}$ (17 mg, $0.45 \mathrm{mmol}, 1.3$ Equiv.). The reaction was carried out under microwave radiation $(270 \mathrm{w})$ for 30 minutes (1.5 minutes intervals). To the mixture was added water $(4 \mathrm{~mL})$ and it was extracted with EtOAc $(4 \times 3 \mathrm{~mL})$, the organic phases were combined, dried over $\mathrm{Na}_{2} \mathrm{SO}_{4}$ and concentrated in vacuo. Flash chromatography (Cyclohexane/EtOAc 10:0 to 7.5:2.5) gave 5' as yellowish oil. (38 mg, $48 \%$ ). A mixture of higher $\mathrm{R}_{f}$ by-products was also isolated (15 mg, 22\%). The ${ }^{1} \mathrm{H}$ NMR spectrum of the mixture showed to separated olefin peaks (6.0 and $6.8 \mathrm{ppm})$ corresponding to the $E$ and $Z$ isomers (8 and 9) . IR (film) $v_{\max } / \mathrm{cm}^{-1}: 2952,2092\left(\mathrm{~N}=\mathrm{N}^{+}=\mathrm{N}^{-}\right) 1721(\mathrm{C}=\mathrm{O}), 1550,1478$, 1453, 1342, 1324, 1238, 1212, 1095, 990, 859, 777, 752, 700, 649. ${ }^{1} \mathrm{H} \mathrm{NMR}\left(\mathrm{CDCl}_{3}, 300 \mathrm{MHz}\right) \delta 1.22(\mathrm{~d}, 3 \mathrm{H}, J 6.6$ $\left.\mathrm{Hz}, \mathrm{CH}_{3}\right), 3.08$ (d, $\left.2 \mathrm{H}, J 7.6 \mathrm{~Hz}, \mathrm{CH}_{2}\right), 3.62-3.67$ (m, $1 \mathrm{H}$, $\mathrm{CH}), 3.82-3.90\left(\mathrm{~m}, 1 \mathrm{H}, J 6.2 \mathrm{~Hz}, \mathrm{CHN}_{3}\right), 3.95$ (s, $3 \mathrm{H}$, $\left.\mathrm{OCH}_{3}\right), 7.16-7.30$ (m, $\left.5 \mathrm{H}, \mathrm{Ar}\right), 8.15$ (s, $\left.1 \mathrm{H}, \mathrm{CH} 5\right) .{ }^{13} \mathrm{CNMR}$ $\left(\mathrm{CDCl}_{3}, 75 \mathrm{MHz}\right): \delta 170.3(\mathrm{C} 2), 161.8(\mathrm{C}=\mathrm{O}), 145.7$ (C4), 137.8 (Ar), 129.0 (Ar), 128.9 (Ar), 128.4 (C5), 126.7 (Ar), $57.6\left(\mathrm{CHN}_{3}\right), 52.4\left(\mathrm{OCH}_{3}\right), 51.1(\mathrm{CH}), 39.4\left(\mathrm{CH}_{2}\right), 17.3$ $\left(\mathrm{CH}_{3}\right) . \mathrm{MS}\left(\mathrm{ESI}^{+}\right) \mathrm{m} / \mathrm{z}$ (rel. intensity) $317.1\left([\mathrm{M}+\mathrm{H}]^{+}, 100 \%\right)$.

Solid-phase coupling reaction (3). To a suspension of Merrifield Resin (1.25 g, $3.12 \mathrm{mmol}, 1.0$ Equiv.), in DMF (9 mL) was added 2 (1.1 g, $3.93 \mathrm{mmol}, 1.1$ Equiv.), $\mathrm{Cs}_{2} \mathrm{CO}_{3}$ (1.5 g, $4.66 \mathrm{mmol}, 1.5$ Equiv.) and KI (568 mg, $3.42 \mathrm{mmol}$, 1.1 Equiv.). The reaction was carried out under microwave radiation (90w) for 12 minutes (45 seconds intervals). Afterwards the resin was washed with DMF ( $5 \mathrm{~mL})$, methanol $(3 \mathrm{~mL})$, water $(10 \mathrm{~mL})$, THF $(5 \mathrm{~mL})$ and diethyl ether $(3 \mathrm{~mL})$. The reaction was sampled during the intervals by stopping the microwave radiation and the FT-IR spectra were recorded as previously reported. ${ }^{7}$ Each sample was washed was describe above.

Solid-phase mesylation (4). To a suspension of 3 (600 $\mathrm{mg}, 1.5 \mathrm{mmol}, 1.0$ Equiv.) in dry $\mathrm{CH}_{2} \mathrm{Cl}_{2}(6 \mathrm{~mL})$ was added dry triethylamine $(0.52 \mathrm{~mL}, 3.75 \mathrm{mmol}, 2.5$ Equiv. $)$ and mesyl chloride ( $0.22 \mathrm{~mL}, 2.80 \mathrm{mmol}, 1.87$ Equiv.). The reaction was carried out at room temperature for 2 hours monitored by FTIR throughout, and then the resin was washed with $\mathrm{CH}_{2} \mathrm{Cl}_{2}$ $(10 \mathrm{~mL}), \mathrm{THF}(10 \mathrm{~mL})$ and diethyl ether $(10 \mathrm{~mL})$.

Solid-phase azide formation (5). To a stirred suspension of 4 (194 mg, $0.48 \mathrm{mmol}, 1.0$ Equiv.) in DMF (1 mL) was added $\mathrm{NaN}_{3}$ (162 mg, 2.49 mmol, 5.2 Equiv.) and $\mathrm{NH}_{4} \mathrm{Cl}$ (28.5 mg, $0.53 \mathrm{mmol}, 1.1$ Equiv.). The reaction was carried out under microwave radiation $(270 \mathrm{w})$ within 30 minutes with 1.5 minutes intervals, and then the resin was washed with methanol (5 mL), THF (3 mL), water (10 mL), THF/ water $(5 \mathrm{~mL}), \mathrm{THF}(3 \mathrm{~mL})$ and diethyl ether $(3 \mathrm{~mL})$.

Solid-phase azide reduction (6). To a suspension of $\mathbf{5}$ 
(155 mg, $0.38 \mathrm{mmol}, 1.0$ Equiv.) in THF ( $3 \mathrm{~mL}$ ) was added triethylamine ( $0.27 \mathrm{~mL}, 1.90 \mathrm{mmol}, 5.0$ Equiv.), thiophenol (0.16 mL, $1.55 \mathrm{mmol}, 4.0$ Equiv.) and $\mathrm{SnCl}_{2} .2 \mathrm{H}_{2} \mathrm{O}(112$ $\mathrm{mg}, 0.43 \mathrm{mmol}, 1.1$ Equiv.). The reaction was stirred at room temperature for $1.5 \mathrm{~h}$. Afterwards the resin was washed with methanol $(5 \mathrm{~mL})$, THF $(3 \mathrm{~mL})$, THF/water $(5 \mathrm{~mL})$, THF (3 mL) and diethyl ether $(3 \mathrm{~mL})$.

Cleavage (7). To a suspension of 6 (177 mg, $0.44 \mathrm{mmol}$, 1.0 Equiv.) in dry $\mathrm{CH}_{2} \mathrm{Cl}_{2}(4 \mathrm{~mL})$ was added freshly prepared $0.2 \mathrm{~mol} \mathrm{~L}^{-1}$ sodium methoxide solution in methanol ( $2 \mathrm{~mL}, 0.4 \mathrm{mmol}, 0.25$ Equiv.). The reaction was stirred for 30 minutes, and the resin was drained with methanol $(3 \mathrm{~mL})$ and diethyl ether $(2 \mathrm{~mL})$. The filtrate was concentrated under vacuum, and the resulting oil was subjected to flash chromatography (cyclohexane/AcEt 10:1) to afford the diastereoisomeric mixture 7 as yellowish oil. (32.7 mg, $26 \%$ overall yield) IR (film) $v_{\max } / \mathrm{cm}^{-1}: 3400$ (br, NH), 3025, 2954, 2920, 1736 (C=O), 1601, 1510, 1493, 1451, 1380 (C-N), 1225, 1113, 1095, 905, 816, 740, 692. ${ }^{1} \mathrm{H} \mathrm{NMR}\left(\mathrm{CDCl}_{3}, 300 \mathrm{MHz}\right) \delta 1.21\left(\mathrm{~d}, 3 \mathrm{H}, J 6.6 \mathrm{~Hz}, \mathrm{CH}_{3}\right)$, 3.12-3.21 (m, $\left.2 \mathrm{H}, \mathrm{CH}_{2}\right), 3.57-3.61\left(\mathrm{~m}, 1 \mathrm{H}, \mathrm{CHNH}_{2}\right), 3.63-$ $3.66(\mathrm{~m}, 1 \mathrm{H}, \mathrm{CH}), 3.91\left(\mathrm{~s}, 3 \mathrm{H}, \mathrm{OCH}_{3}\right), 4.60-5.00(\mathrm{br} \mathrm{s}, 2 \mathrm{H}$, $\left.\mathrm{NH}_{2}\right), 7.07-7.27(\mathrm{~m}, 5 \mathrm{H}, \mathrm{Ar}), 7.99$ (s, $\left.1 \mathrm{H}, \mathrm{CH} 5\right) .{ }^{13} \mathrm{C} \mathrm{NMR}$ $\left(\mathrm{CDCl}_{3}, 75 \mathrm{MHz}\right): \delta 171.4(\mathrm{C} 2), 161.8(\mathrm{C}=\mathrm{O}), 146.4(\mathrm{C} 4)$, 137.9 (Ar), 128.9 (Ar), 128.5 (Ar), 127.2 (C5), 126.6 (Ar), $52.4\left(\mathrm{OCH}_{3}\right), 50.4(\mathrm{CH}), 50.0\left(\mathrm{CHNH}_{2}\right), 37.4\left(\mathrm{CH}_{2}\right), 17.8$ $\left(\mathrm{CH}_{3}\right)$. MS (ESI $\left.{ }^{+}\right) \mathrm{m} / \mathrm{z}$ (rel. intensity) $291.1\left([\mathrm{M}+\mathrm{H}]^{+}, 100 \%\right)$.

\section{Acknowledgments}

We are grateful for funding from Conselho Nacional de Pesquisa e Desenvolvimento Científico-CNPq and Asosiación de Universidades del Grupo MontevideoAUGM. We also wish to thank Prof. Ana Maria Bergold for providing the FT-IR spectrometer (LAPPS, UFRGS), Joyce C. Espindola (IQ, UFRGS) and Horacio Pezaroglo (UDELAR) for NMR analyses and Cedric Graebin (LASOM) for FT-IR analyses.

\section{References}

1. Winter, M.; Warrass, R. In Combinatorial Chemistry Practical Approach; H. Fenniri, ed.; Oxford University Press: Oxford, 2000 , ch. 6 , and references therein.
2. Graebin, C. S.; Eifler-Lima, V. L.; Quim. Nova. 2005, 28, 73.

3. Lorgé, F.; Wagner, A.; Mioskowski, C.; J. Comb. Chem. 1999, 1, 25; Rousselot-Pailley, P.; Ede, N. J.; Lippens, G.; J. Comb. Chem. 2001, 3, 559; Grice, P.; Leach, A. G.; Ley, S. V.; Massi, A.; Mynett, D. M.; J. Comb. Chem. 2000, 2, 491; Yan, B.; Li, W.; J. Org. Chem. 1997, 62, 9354.

4. Yan, B.; Gremlich, H. U.; J. Chromatography B. 1999, 725, 91; Yan, B.; Gremlich, H. U.; Moss, S.; Coppola, G. M.; Sun, Q.; Liu, L.; J. Comb. Chem. 1999, 1, 46.

5. Groweiss, A.; Shmueli, U.; Kashman, Y.; Tetrahedron Lett. 1980, 21, 3629; Okuda, R.; Sheuer, P. J.; Experientia 1985, 41, 1355; Kashman, Y.; Groweiss, A.; Lidor, R.; Blasberger, D.; Carmely, S.; Tetrahedron 1985, 41, 1905; Blasberger, D.; Carmely, S.; Cojocaru, M.; Spector, I.; Shochet, N. R.; Kashman, Y.; Liebigs Ann. Chem. 1989, 1171; Northcote, P.; Blunt, J. W.; Munro, M. H.; Tetrahedron Lett. 1991, 32, 6411; Kobayashi, J.; Kondo, K.; Ishibashi, M.; Wälchli, M. R.; Nakamura, T.; J. Am. Chem. Soc. 1993, 115, 6661; Gerwick, W. H.; Proteau, P. J.; Nagle, D. G.; Hamet, E.; Blokkin, A.; State, D.; J. Org. Chem. 1994, 59, 1243.

6. Crews, P.; Kakaou, Y.; Quiñoa, E.; J. Am. Chem. Soc. 1988, 110, 4365 .

7. Antonow, D.; Graebin, C. S.; Eifler-Lima, V. L.; J. Braz. Chem. Soc. 2004, 15, 782.

8. Mahler, S. G.; Serra, G. L.; Antonow, D.; Manta, E.; Tetrahedron Lett. 2001, 42, 8143.

9. Gisin, B. F.; Helv. Chim. Acta. 1973, 56, 1476; Anuradha, M. V.; Ravindranath, B.; Tetrahedron 1995, 51, 5671.

10. Salunkhe, A. M.; Ramachandran, P. V.; Brown, H. C.; Tetrahedron 2002, 58, 10059; Bosch, I.; Costa, A. M.; Martin, M.; Urpi, F.; Vilarrasa, J.; Org. Lett. 2000, 2, 397; Ding, J. C.; Wu, H. Y.; Chin. Chem. Lett. 2001, 12, 662; Kamal, A.; Reddy, G. S. K.; Reddy, K. L.; Tetrahedron Lett. 2001, 42, 6969; Kamal, A.; Reddy, K. S.; Prasad, B. R.; Babu, A. H.; Ramana, A. V.; Tetrahedron Lett. 2004, 45, 6517.

11. Frenette, R.; Friesen, R. W.; Tetrahedron Lett. 1994, 35, 9177.

12. Perrin, D. D.; Armarego, W. L. F.; Purification of Laboratory Chemicals, $3^{\text {rd }}$ ed., Pergamon Press: Oxford, 1988.

Received: October 26, 2004 Published on the web: March 30, 2005 